\title{
MODELLING ENVIRONMENTAL ACTIONS OF CORPORATE SUSTAINABLE ACTIVITY: EVIDENCE FROM LITHUANIA
}

\author{
Drejeris, R., Oželienè, D.
}

Rolandas Drejeris, Danguolé Oželiené / Vilnius Gediminas Technical University, Faculty of Business Management, Department of Management, Saulètekio al. 11, 10223 Vilnius, Lithuania. Email: rolandas.drejeris@vgtu.It;vvvk@vgtu.It.

\begin{abstract}
Many sources have been noted that environmental protection measures are economically beneficial as their application allows to increase the efficiency of resource use, reduce operating costs, increase company's profit and also to avoid ecological accidents. The aim of the article is to analyse the environmental component of sustainable development in terms of its expression in the corporate activities. And according to results of analysis to create a model whose application not only demonstrates the actions needed to strengthen the environmental sustainability of corporations, but also allows an assessment of their potential and readiness for sustainable development. The elements of created model define the environmental actions to be taken also provide structural basis for implementation of these processes. So, the model serves as an instrument to show directions of improving the environmental sustainability of the Company's activities. Research was based by using the methods of logical assessment, systematization, and comparison of information, selecting the most important information, which describes the environmental sustainability. The application of the actions in the company's activity would allow to gradually approach the sustainability of the company activities. Possibility to use the model and its suitability has been approved by Lithuanian construction companies. The application of the model will allow companies better implementation environmental actions which will improve the company's results of economic performance and will also help public institutions distributing funds for environmental purposes by projects. Construction companies were ranked in accordance with possibility to implement environmental measures by use proposed methodology.
\end{abstract}

Keywords: corporate sustainability; environmental protection; strategic decisions, modelling

JEL Classification: M40, M19, O21

\section{Introduction}

The commitment of corporations to environmental sustainability and the impact on their performance are often discussed in research. The scientific literature has a strong focus on the growing demand for environmental activity, but there is a lack of information about these specific environmental actions which should be carried out at company level if they 
pursue social responsibility. The activities of companies are enabled by the use of material, human resources and energy acquired from the internal and external environment. Each company seeks to get the maximum amount of added value with minimal resources. Unavoidably, waste is generated in the process and then discarded into the environment. Global environmental pollution has been the first signal that economic development can have serious consequences for future generations. These assumptions have led to the emergence of a concept of sustainable development (Paul et al., 2014). Barbien (2013) provides a more categorical opinion that the economic system is completely dependent on ecosystems.

Guidelines on how to achieve greater sustainability in order to improve economic performance are still widely debated by authors and practice-oriented minds. These guidelines could be later used by start-ups and well developed companies concerned about environmental sustainability. The absence of a universal model detailing implementation of actions directed towards environmental sustainability is one of the greatest issues currently faced by both business theorists and practitioners. The methodological potential for environmental action selection is especially poor. The high demand for a solution to this problem and its practical and scientific topicality motivated the present research into this field. The aim of the research is firstly to examine the relevance of environmental protection as a component of sustainable activity and secondly to present a model which would determine possible routes for implementing the commonly accepted environmental actions associated with sustainable development. The model would additionally serve as an instrument to assess the readiness and possibility to develop environmental actions in any corporate sustainable activity.

Research is based on analysis of authors' opinions through the methods of logical assessment of situations, systematization of sometimes controversial approaches and comparison of information. The most important information describing environmental sustainability was ultimately selected and the possibility of individual steps in the corporate manufacturing process being sustainable was estimated. Then possible actions to strengthen the environmental sustainability of corporations were presented and clarified. After, the possibility of increasing efficiency in business process was evaluated and areas that require improvement were pinpointed in accordance with the approach of sustainability. Based on this information, a new model of environmental actions for corporate sustainable activity was created. As a last step, the suitability of this model was tested in Lithuanian construction companies.

\section{Discussion of the requirements for the process model of corporate environmental protection}

Certain stakeholder groups may always have an impact on the reduction of environmental effect (Doh and Guay, 2006). Therefore, the corporation has to make an assessment of possibilities and present it to the shareholders, employees, customers, the public, competitors, associations and trade unions and explain the potential positive effect of their probable actions. These entities must recognize that environmental protection policy is undoubtedly beneficial in the long run as it increases the company's profit by gradually increasing the stock and company value (Genc, 2013). Surrounding environment is the medium in which businesses perform their functions, therefore, companies must protect 
and care for the environment as they use its resources. According to Paul et al. (2014) the environmental protection at a company's operational level can be either targeted at its products or at its processes. Focusing on the products entails greater efforts to ensure product quality while also protecting the company's image from the negative light in which environmentally unfriendly products are presented. Focusing on the processes involves minimization of waste and the introduction of environmental technologies for pollution prevention. Compliance with both approaches can act as guidance cues and help companies follow environmental requirements.

In a related manner, some authors have examined the impact that business activities have on the environment (Kshatri and Chouksey, 2014). They invite readers to pay attention to the preservance of air, soil, water quality and biodiversity, stating that a sustainable system must be based on resources that will not be depleted over a period of time and will not generate unacceptable environmental pollution. Consequently, our proposed environmental action model must entail components which would foresee and account for the reduction of resource use, which in turn reduces negative environmental impacts and contributes to the more sustainable functioning of environmental systems (Ayres, 2008).

From here, a question emerges: how to achieve a customer-satisfying result with less resources? The importance of this issue and the way in which to distinguish between the positive impact on the environment generated by the reduction of used material resources and used energy resources is described by Glavič and Lukman (2007). The view that separates these two types of resources can be welcomed, since the origin of these resources and the possibilities for reducing them are fundamentally different. The process of reducing the use of raw materials and energy resources may also be aimed at changing (or improving) technology. Therefore, the environmental action model should also include the components which would direct reduction of resource use.

The model should additionally entail a component that includes the assessment of the possibilities for reducing the use of raw materials. The results of this assessment would allow companies to choose the most appropriate actions for their current situation. The possibilities for reducing the use of raw materials has been the subject of many previous studies by energy specialists and analyses by management authors (Tietenberg and Lewis, 2018; Hellstrom, 2007 and also others). Lately, many authors have revealed the negative impact of industrial pollution on the environment. For example, some have examined the differences between organic and non-organic products on the (Dangelico and Pujari, 2010; Russell and Shiang, 2013 and others). Dangelico and Pujari (2010) found that the manufacturing of organic products has dramatically decreased the negative impact on the environment during the whole product life cycle. They presented the results of the study by providing specific indicators detailing the dynamics of air, water and soil. Structured research data from various other authors has further demonstrated the negative impact of pollution on certain environmental indicators (Cheng and Shiu, 2012). Consequently, the pollution reduction processes must be reflected in a company's sustainable business model.

The introduction of pollution reduction processes is undoubtedly related to changes in waste quantities. In order to have an uncontaminated environment, it is necessary to create an efficient waste management system that helps to reduce the generation of waste and its negative impact on the environment and human health. However, production waste that 
may be used in other activities cannot be considered as waste. This is confirmed by authors, who present a waste management model tailored to a company's sustainable activity (Elsaid and Agnezzaf, 2015). The aforementioned authors ensure that proper waste management is one of the guarantors of the success of a sustainable activity. The authors claim that a company can achieve better results by potentially reducing the amount of waste. Therefore, the solution of waste reduction issues must be expressed in the corporate environmental action model.

The search for possibilities to apply actions presented in the model should reflect the essence of the model. In addition to the aforementioned components necessary to the model, the model should also contain a component for the assessment of search results, describing an assessment procedure, and another component for strategic decisions based on the evaluation of results.

The following sections are further divided by subheadings which should provide a concise and precise description of the experimental results, their interpretation and the experimental conclusions that can be drawn.

\section{Process model formation of corporate environmental protection}

Sustainable development is a dynamic and, in principle, endless process of society's development, therefore its goals, tasks and means of implementation can change over time. In order to move towards more sustainable development, it is necessary to change the thinking of individuals and organizations, to formulate sustainable development goals as prerequisites for social responsibility and to determine the direction of their implementation. Such would be the goal of the model being developed. The main components of the constructed model should be the reduction of four factors: pollution, waste, raw materials and energy resources. It should also include evaluation of the application of these processes, result processing and strategic decision making. The need for these components is reflected by requirements in a company's environmental action implementation model. In the later stages of model formation, it is necessary to determine the sequential order of the above components. For that purpose, it is advisable to follow the cost-benefit analysis principle and give priority to those components that provide the least costly activity and which execution is most likely to be the most effective. In this regard, the first steps should be taken in the resource reduction component. Lower spending on resource purchases would increase the company's profitability and direct the company's operations towards sustainability. The model for implementing environmental actions is presented in the Figure 1.

Companies which have decided to pursue sustainable environmental practices face difficulties in determining the priorities in the implementation of measures mentioned in the model. This is a multi-criteria task, since one tool may be more suitable for one criterion and another more appropriate for others. Therefore, it is necessary to apply multi-criteria assessment methods to prioritize. The essence of the evaluation criteria is primarily to express the effectiveness of the measures from the environmental point of view and the possibilities of the company. In the following sections of this chapter there are detailed actions envisaged in the components of the proposed model. It can be argued that a 
company that has implemented all the measures provided for in the model will be environmentally sustainable.

However, the mere pursuit of at least a part of them is welcome, since the foresight of environmental measures in the company's strategy and their implementation will certainly bring economic benefits (Kshatri and Chouksey, 2014). This model will be used as a tool for companies seeking to develop environmentally sustainable activity.

Figure 1 | Process model of corporate environmental protection

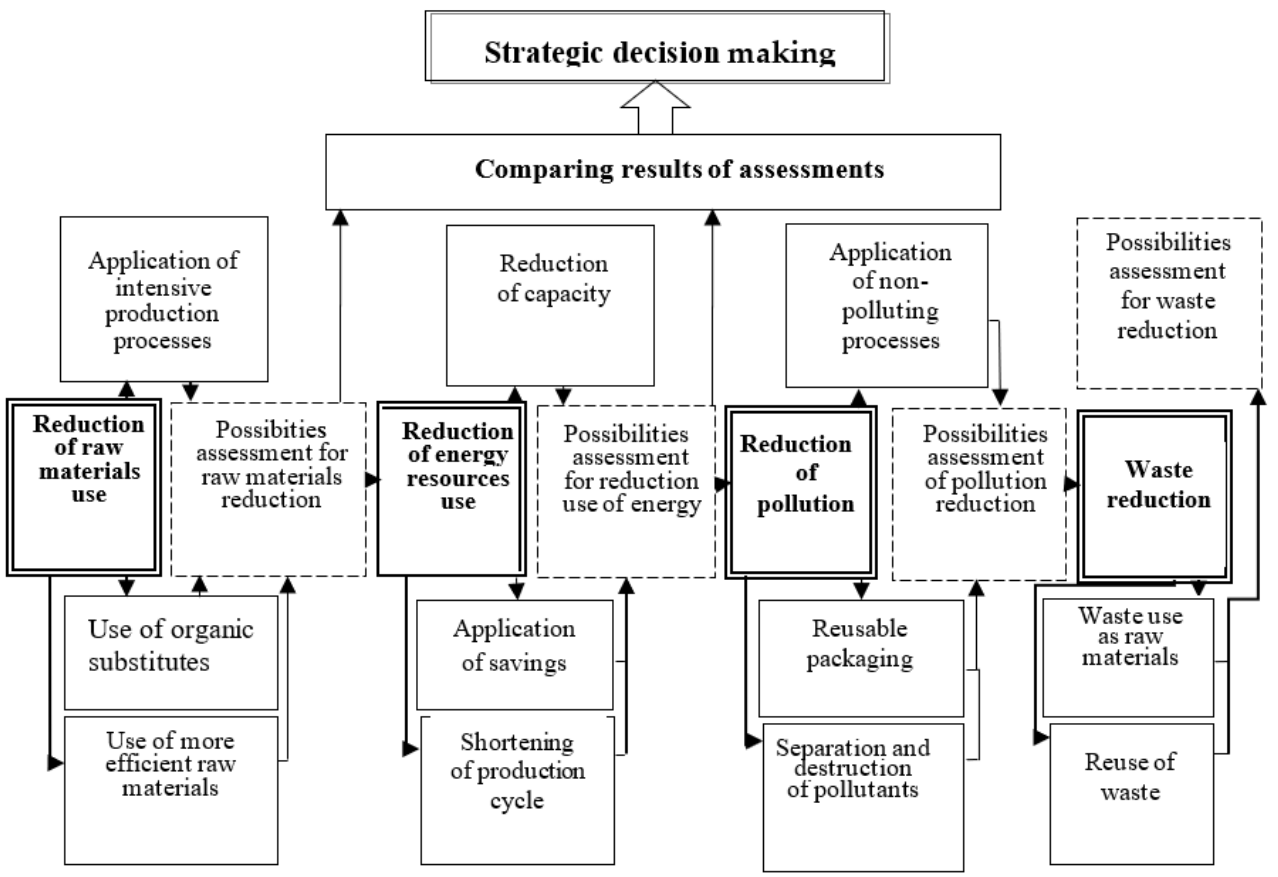

Source: authors

Next, all the components of the model are explained, detailing the processes required to achieve environmental sustainability.

\subsection{Reduction of raw materials use}

Rothaermel (2016) argues that company's provisions for reducing resources must be reflected in the company's strategy. The aforementioned author emphasizes that the implementation of measures to reduce resources must give companies a competitive edge. One of reductions of several resources use is the application of intensive technology. Intensive technology means a tight production mode that uses certain tools to accelerate processes to get the best result at the lowest cost (Rothaermel, 2016). Thus, the search for possibilities of resources reduction in various sources is a continuous process. Therefore, corporate executives or responsible employees need to be constantly interested in scientific advances in technology development, to follow global trends in the field of new technologies in order to achieve a competitive advantage in the company's operations. Companies - the market leaders, which have enough funds, can make orders in research 
institutions for new technologies, saving on raw materials creation and the first ones can use the results of inventions. Thus, the first way to reduce the use of resources must be related to the search for the use of intensive technologies. The production process involves the use of various materials, some of which become waste or pollutants that are harmful to the environment.

The use of green substitutes could reduce the negative environmental impact. Together with the substitution search it is advisable to look for opportunities to use more efficient raw materials. Further there are suggested managerial solutions for reducing energy resources. Their technical justification is the object of engineering research.

\section{Application of intensive production processes}

Intensive production processes, when applied in practice, allow for the shortening of the production cycle without reducing quality indicators. Magnusson and Johansson (2008) confirm that modern mass production has become less significant because product have to increasingly be adapted to the needs of consumers. Therefore, production changes and production process intensification are required. It has been observed that the application of some intensive production technologies to the food or pharmaceutical industries does improve product quality indicators. In the field of medical services, the latest scientific achievements also make it possible to shorten the cycle for the provision of these services.

The intensification of product manufacturing processes may also be related to the more efficient use of raw materials, which will be discussed in the next section. The process intensification is most often related to the creation and implementation of innovation. Therefore, intensification is typically based on employee knowledge and the development of new technologies is exclusively subject to scientific institutions' activities. However, it takes time for industrial enterprises to adopt such knowledge-based intensive technologies and better results are achieved by those companies which are quicker to employ intensifying product manufacturing processes. (Everingham at al., 2008). When this is not possible, the production process may be intensified artificially through the creation of more favourable conditions, as argued by Skocaj et al. (2013). This approach is characteristic of the agricultural, medical and food industries. For example, in agriculture, this is evident in the use of growth-enhancing supplements being given to livestock. In the services sector, the deployment of technologies tailored to different users may be used for effective intensification.

The search for favourable conditions is characteristic of the agricultural, medical and food industries. Companies need to actively and thoroughly analyse existing technological processes in order to avoid unnecessary actions and thus reduce the cycle of manufacturing/service provision and potentially reduce operating costs. In the services sector, costs are reduced by technologies tailored to different users. Enhancing manufacturing activities will give companies a competitive advantage, so constant exploration of options should be a permanent process for both manufacturing and service companies. For example, in agriculture, it is expedient to use intensive animal husbandry technologies (when certain growth-enhancing supplements are given to livestock) and intensive crop production technologies (Brown et al., 2017). In the construction sector, they use certain ingredients (Shelton et al., 2016), which provide better properties to materials (strength, durability). In the pharmaceutical industry reaction accelerators are widely used 
as well (Narayana et al., 2012). Confectionery industry uses confectionery additives, which allow reducing the use of raw materials and achieving a result which is just as good.

\section{Use of organic substitutes}

Quoting M. E. Porter, the emergence of substitutes was labelled by Fifka with Berg (2014) as a threat to companies in developing and implementing a competitive strategy. However, the application of substitutes in manufacturing is a possible first step towards the use of environmentally friendly resources. While the term substitute is usually attributed to the use of alternative food products, it is ultimately prudent for the use of substitutes to be considered in other industries when designing a new product. The whole product manufacturing cycle should be reviewed in an attempt to find any possibilities for replacing environmentally unfriendly materials for friendly ones. The key is to find a way to replace materials with a long decomposition process with natural ones that decompose faster. This allows for less waste overall as fewer primary resources must be used to assist in the disposal process thereby giving less pollution to the environment. A few examples of this would be to use wood in furniture and toy manufacturing, organic clue instead of nails in construction, and to use natural materials instead of synthetic ones in the cosmetics industry.

A welcome choice is to produce wooden furniture, toys instead of plastic ones, use environmentally friendly, natural-looking wall-papers, organic glue instead of nails, avoid plastic packaging, and use natural materials instead of the previously popular synthetic ones in the cosmetics industry. Advanced green chemistry methods offer solvents derived from natural and/or renewable sources, namely biologically based molecular solvents, ionic liquids consisting exclusively of biomaterials and natural resources (Pena-Pereira et al., 2015). The efforts to explore the options in attempt to use materials that are environmentally friendly should be a kind of checkpoint for business executives' activities and this activity should therefore be included in the corporate strategy for sustainable business.

\section{Use of more efficient raw materials}

The use of more efficient raw materials is understood as the discovery of entirely new raw materials which would speed up the production process and/or reduce the amount of resources needed within it. In other words, it means the creation of more expensive products with lower costs. Nevertheless, these materials can also serve to reduce energy consumption in the production process, thereby limiting environmental impact. This may be observed in the chemical industry and the role of catalysts, a substance that increases the rate of chemical reaction but is not consumed in the reaction, within it. Such materials are being developed, refined and used not only in chemistry, but also in medicine and the food industry. They have also been observed in the construction and tech industries where the substances selected for usage allow the product life cycle to be extended. For example, a computer upgraded to extend its lifespan includes expansion of operational memory which runs on new memory modules using the same amount of power, but the speed of the computer increases.

With changing consumer needs, the constant search for better-performing materials is an inevitable process. It is precisely the search for such materials that is characteristic of the scientific institutions that create innovations in an array of industries. Modern companies 
should thus keep track of the latest news in the world of science regarding the development or use of materials. They should seek to keep pace with global leaders in order to overcome less flexible rivals in a competitive struggle for better performance. The emergence of more efficient materials on the market will ultimately require the immediate reorganization of production/service provision processes, which is crucial for companies wishing to survive in a competitive struggle.

Hellstrom (2007) is looking into the more efficient usage of materials and states that in the course of development of eco-innovations, the following actions should be taken: reduction of material components in products, reduction of the quantity of substances in products and prolongation of the product lifetime using more efficient substances. The aforementioned author also suggests looking for opportunities to expand product use functions which could include using the product not only for its direct use but also for other functions. Such opportunities can arise from the use of more efficient materials in the production of the product. Furthermore, Hellstrom (2007) sees the use of more environmentally friendly substances in the production process as an opportunity to reduce the risk of health hazards.

\section{Assessment of the results of the search for opportunities to reduce raw materials}

Reducing the use of raw materials in companies is possible through the three methods discussed in the previous sections. After applying these methods, it is then necessary to evaluate the results obtained in searching for raw material reduction possibilities. The purpose of the evaluation is to rank all the aforementioned actions according to their importance and application possibilities. The assessment should be carried out with consideration to the financial and technological resource of the company, in addition to the capabilities of its employees. Furthermore, consideration should be given to the success of earlier implementations of opportunities to reduce raw materials, if applicable. The easiest way of carrying out this evaluation is with the assistance of the multi-criteria SAW method. The results of the evaluation should reflect the overall sustainable development strategy of the company under evaluation and the leader of the company should be the initiator of the evaluation and its chief overseer. Nevertheless, the involvement of other employees in the evaluation is a good idea as this most always yields a better result, especially in social terms.

\subsection{Reducing the use of energy resources}

The main objective of the future energy is to ensure the state's security and sustainable development in accordance with environmental requirements. For that, it is necessary to meet the consumption needs of energy resources using a variety of primary energy sources, increase the efficiency of energy production, transmission, distribution and consumption, guarantee the affordable cost of these resources and provide reliable and of appropriate quality to the end users. It is believed that in the future, the energy market will be expanded and improved, involving more and more participants in this business and increasing the efficiency of the energy sector. In order to emphasize the aspects of reducing energy resources due to their unique origin and importance, in the model they are singled out with a separate component. Enterprises can foresee the reduction of their energy resources in 4 directions: using alternative energy sources, reducing the capacity of 
the equipment used, applying savings mode, regulating the use of energy resources or using more efficient raw materials.

\section{Use of alternative energy resources}

As the population grows, there is a growing need for energy too. Already at the end of the last century, in order to compensate for the bulk of fuel consumption in industrial enterprises, power plants and heating houses, the import of petroleum products, especially fuel oil, from the exporting countries of these products increased very quickly. Comparatively cheap oil products and natural gas gradually have forced out local energy resources prevailing on a balance sheet of some countries (Lithuania as well). The damage to nature and a human being caused by the use of fossil resources to produce energy has been proven in many scientific works around the world. Authors warn manufacturing companies and predict catastrophic environmental and human impacts without reducing the pace of use of such resources globally. In this respect, the proper application of environmental measures is also closely related to the solution of social problems. So, the solution is the use of alternative energy sources. Such sources as for example, agricultural enterprises include biomass, timber, straw, energy plants and biogas, whose production would help to consume various organic waste without harming nature, as well as companies that could harvest solar energy, wind and other environmentally friendly sources. Incidentally, such energy production could also create new jobs.

For example, in agriculture alternative sources of energy can be found in livestock facilities located in a separate municipality, wastewater treatment plants (biogas), industrial plants that dispose of organic waste, municipal waste, the sun, wind, hydropower, geothermal energy, etc. These would be traditional alternative sources of energy. An alternative energy could be derived from flood-tides, micro-organisms, and cosmic energy. These energygenerating methods are still the object of research.

A more rational use of funds for energy production is the one when energy is produced centrally and then distributed to enterprises and household customers. If companies are not able to obtain energy from alternative energy sources in a centralized manner, it is appropriate, from the point of view of sustainability, to organize energy production from alternative sources independently. Alternatively, renewable power engineering is currently not only a fashionable term, but also a relevant and promising field of energy production, so the executives of the companies seeking sustainable business need to evaluate all possibilities of choosing an alternative source of energy. It would be worthwhile to assess the effectiveness of investments, the degree of risk and make the necessary conclusions.

\section{Reduction of capacity required for the production of products/provision of services}

In recent decades, companies around the world are struggling to find ways to increase energy consumption efficiency. The increase of efficiency is aimed at reducing energy consumption because of the constantly rising prices of energy resources, increasing energy demand and still tougher up-to-date environmental requirements.

Another direction that could reduce energy consumption in the company would be the introduction of energy saving equipment. Modern scientific discoveries are geared towards the creation of lower capacity but higher productivity devices. Currently, only some of the individual components are used in the automotive, food and heat industry, the application of 
which increases the scale (capacity) of process execution without the use of additional energy resources. Nowadays, such technologies are being developed that would reduce the electrical power of the equipment and allow less electricity to be consumed without compromising the quality of the product and without reducing production efficiency. Household appliances are also being designed and manufactured with lower power engines, whose performance remains or even increases.

Knowledge of information about electricity consumption will make it easier for business executives to decide on the choice of equipment. The change of equipment is inevitable, as companies aim to gain a competitive advantage in their activities, and this is achieved through the reduction of cost. The investment always is required for the purchase of new equipment, and its return (payback time) must be calculated in order to compare some results of different decisions. If the net income is uneven, the payback period is determined by the sequential summation of revenue and time calculation until the amount of net proceeds is equal to the amount of the investment. This calculation is most often used by small businesses due to the possibility to assess the current situation and business conditions. New equipment consumes less energy resources, or if made from environmentally friendly materials - more compact, durable and reliable more.

\section{Application of savings mode}

One of the most important factors influencing energy consumption is its rationing. For example, at present, in many manufacturing companies, the rationing index $\omega$ which defines the relative energy consumption required for one product is used. It can be calculated for all types of energy used (electricity, heat, etc.) This index indicates the efficiency of the use of energy resources. The efficient use of energy resources affects product costs, and cost savings will allow to enlarge the company's profits, which growth will probably make it possible to improve the working conditions of employees, and their motivation to work even better. It is clear that the reduction of energy resources, expressed as an environmental goal, will also help to achieve the economic and social goals of the company. The comparative energy consumption indicator $(\omega)$ is convenient in that is very easy to be determined (Lawrence et. al., 2019):

$$
\omega=\frac{W_{e}}{n}
$$

where $W_{e}$ is the electricity consumption for a certain period of time and $n$ product quantity over the same period. A downward trend in the indicator would imply a more sustainable use of energy.

It is useful for companies to know the dynamics of this indicator. Its downward trend indicates a more sustainable use of energy in terms of sustainability. In order to use energy resources economically, it is first and foremost to know their consumption. As a result, the automation, remote accounting equipment is being used for the accounting of energy resources. Savings mode is only possible with a clear view of the consumption of energy resources at each stage of the production / service provision. Thus, reduction of energy resources use would enable economic, social and environmental policy objectives to be realized. 


\section{Shortening of the production cycle}

The shortening of the production cycle is always associated with a lower consumption of energy resources and a faster turnover of funds. According to Liddell (2008), in order to shorten the production cycle, it is advisable to follow Toyota's best practices which advocate for avoiding the seven losses that do not contribute to value creation: transportation, surplus stocks, surplus movement, waiting, additional processes, surplus production and defects. These seven losses reduce productivity, increase production costs, impede timely production deliveries and extend the production cycle. In order to avoid such losses, the volume of production processes should be tied to real demand, while reducing the formation of unnecessary stocks in the supply chain. It is therefore advisable for companies to move to a new production model which reduces batches and takes into account customer needs, thereby more precisely combining demand and production capacity.

The time of the production cycle can also be reduced by other means, for example, by reducing operational suitability. This can be done by installing advanced technologies, updating equipment and increasing work efficiency by means of rationally harmonized operations. However, given that at many stages of production there are compulsory auxiliary processes of a certain type that do not contribute to the creation of value, another way of shortening the production cycle is to look for ways of accelerating auxiliary processes by reducing the cost of these processes. Automating control operations, shortening production breaks, applying proper planning to production processes and using flexible production principles can also shorten the production cycle.

The reduction of the production cycle is, in principle, possible by other appropriate management decisions. For example, shortening production breaks, rational organisation of workplaces and distribution of work, proper planning of production processes, optimization of work and rest regimes, i.e. using flexible production principles and rational work schedules.

\section{Evaluation of the search results for reducing the use of energy resources}

The search for options to reduce energy resources is a constant concern for a company's executives, as energy resources represent a high proportion of the cost of many products. First of all, it is expedient for companies to review their business plans and to look for organizational opportunities to reduce the use of energy resources because these measures require the least investment. Companies may also look to take advantage of the programs of many European governments which encourage business entities to use renewable energy resources. In assessing the potential for reducing the use of energy resources, the economic effect of the application of the measure is the most important, as are technical possibilities. Nevertheless, consideration should also be given to human resources as companies installing equipment for the use of renewable energy sources may need to hire additional personnel to operate and maintain such equipment.

\subsection{Reduction of pollution}

Reducing pollution by way of carrying out clean production is undoubtedly one of the most important tasks for achieving a sustainable business. In the context of sustainable development, the environment has two main functions: to supply natural resources to the 
economic sector and to absorb waste generated in the production and consumption process, ensuring both production and environmental stability. Companies do not often acknowledge that their activities have a certain environmental impact in order that they may maximize profits at the lowest cost. According to Barbien (2013) and Paul et al. (2014), the consequences are evident: air and water pollution is increasing, resulting in the disappearance of the ozone layer and an increase of carbon dioxide in the atmosphere. This pollution can threaten human health, natural ecosystems and damage tangible property.

\section{Packaging of products into a changeable package}

Properly used packaging helps reduce environmental impacts and allows for the more efficient use of available resources while also reducing pollution (Thoren and Vinberg, 2000). Reusable packaging saves raw materials and creates less pollution but its processing requires more costs. Thus, the expediency of the use of reusable packaging has to be determined through the Life Cycle Assessment (LCA) system (Roberts et al., 2010). Belanger and Crossler (2011) argue that improving the packaging management process is advisable in the best environmental sense through the use of universal reusable packaging (i.e. suitable for the packaging of several types of products). Other authors suggest using a smart package (changing colour over time, self-decomposing, etc.) to reduce environmental pollution.

Corporate executives must ultimately track innovations in packaging and consider opportunities to incorporate such innovations into their company practices in order to reduce their environmental impact. A simple way this can be done is to have environmental requirements that all suppliers must adhere to and to select the suppliers who deliver raw materials in environmentally friendly packaging.

\section{Application of non-polluting manufacturing processes in the activities of companies}

Genc (2013) identifies some of the directions of production improvement, the first being to prevent pollution from rising by reducing emissions, runoff and depletion levels. The second direction is the management of the product, which focuses on the substantial reduction of emissions, and also the reduction of unfavourable environmental impacts throughout the whole product life cycle. This involves the search for possibilities for the inclusion of the end of the product life cycle into the next product launch start. The third and hardest option is to use "clean" technologies that do not cause any harmful emissions at all. It should be emphasized that production processes can be destroying pollutants (destructive) and nondestroying (non-destructive). It is the non-destructive processes that require the use of other methods for the destruction of pollutants.

Ultimately, improvement or renewal of existing production processes in the company in order to reduce environmental pollution is an opportunity to strengthen a company's competitive position. Modern activity encourages the use of less resource and more orientated to raw materials obtained from recycling of production waste. International regulatory documents provide for the development and application of national or international standards for the emission of harmful substances in industrial processes and other measures to achieve human health and environmental objectives and to improve technologies for limiting toxic emitters. 


\section{Separation and destruction of pollutants}

Separation of pollutants means the removal of certain amounts of them from the air, soil and groundwater. Companies seeking to achieve environmental friendliness should strive to provide for the possibility of separating contaminants so that they do not enter the air or soil. Physical methods are the most suitable for achieving this, which generally involves using various filters, that is barriers accumulating harmful substances, being removed and used in other ways. In this way, the waste is not necessarily completely cleaned, but its spread is potentially stopped. An alternative to physical methods are thermal methods that are based on the combustion or ignition of pollutants. Chemical decontamination is also possible, when pollutants are exposed to chemicals to form less hazardous or completely non-hazardous compounds. Biological methods are another alternative which destroy or transform contaminants by introducing new or activating naturally existing microorganisms (Pera-Pereira et al., 2015).

Business executives need to be aware of all the possibilities for separating pollutants in production processes and applying these methods in the product's production cycle. When poisonous contaminants enter the air, soil or water, many living animals and plants die there, nature disappears. Therefore, corporate environmental protection is one of the most important principles of sustainable business.

\section{Assessment of the results of the search for pollution reduction options}

The potential for reducing pollution usually involves improving the production process or creating a more appropriate organization of work. This often requires additional investment. The choice of method for reducing pollution is determined by the level of environmental impact. The best method is one whose application effectively diminishes harmful environmental impact and/or shortens this impact. Start-up companies are in an ideal position to choose non-polluting manufacturing technologies and it is expedient for established companies to find funds for the deployment of low-emission technologies. The result of the feasibility assessment is the ranking of selected methods, taking into account the level of negative environmental impact and the financial capabilities of enterprises.

The negative effects of pollution can even affect the health of employees, so improving action in this respect could potentially reduce employee illness and thus also address some social problems.

\subsection{Reduction of production waste}

The reduction of production waste is often viewed as one of the success factors of a production or service provision company, as the cost of a product or service decreases as the amount of industrial waste declines, thereby leading to profit growth. Natural resources used in the production process are emitted into the environment in the form of various types of waste and the issue is that modern industries and society use natural resources and produce waste at a rate that surpasses the capacity of nature to transform waste into environmentally beneficial materials and resources (Paul et al, 2014; Barbien, 2013). According to Dornfeld et al. (2013), sustainability can only be considered in the context of a closed system which purports that the amount of existing substances on the Earth is limited. The more kinds of waste that are emitted in a closed system, the less there will 
remain of the high-quality materials suitable for use in the future. A way to reduce waste is to recycle it and/or reuse it in other products.

\section{Use of waste as raw materials}

Today with the application of modern computerized inventory management methods, the implementation of "precise timeliness" systems, robotization of the manufacturing processes and automation, waste quantities in production are slowly being minimized. The most appropriate scheme of organization of production in this respect is the application of waste-free technology. This technology promotes the concept of waste from one production process being used to furnish another production process, otherwise known as secondary recycling. The most common examples of such production are found in the construction industry and food production.

Another way to recycle waste is to use it to improve the production processes of other products. For example, organic waste can be used for feed, deposited, composted, ploughed in fields or processed into biofuels or biogas. However, the simplest way to reuse waste is to burn it in order to obtain the heat needed to produce the product or to simply sell it for additional revenue. In the presented model (Figure 1), the waste reduction component consists of 2 parts: waste recycling as a production without waste and the use of waste for improving the production processes of another product. They are different in nature and content, but similar in result.

Production without waste is the result of future decisions. According to Poile and Safayen (2016) computable modelling is an appropriate method for developing such production schemes. Computable modelling is a reliable computer analysis of processes, constructions and systems (Poile and Safayeni, 2016). So, in turn, waste can be raw materials for other industrial or natural systems and have a positive impact on the environment and the economy.

\section{Assessment of waste reduction options}

As with other options, after analysing the possibilities for industrial waste reduction, they should be ranked according to the importance and predicted results of implementation. Both established and start-up companies have to optimize the amount of production waste and this is often done through the search for waste reduction opportunities. For the reduction of waste in established enterprises, it is sometimes sufficient to tighten control over the production or service provision through the introduction of certain control management systems. Control methods work in the face of staff negligence or inappropriate work attitudes and when applied appropriately allow for the optimization of waste quantities in the least costly way. On the contrary, optimizing product production processes in terms of raw material consumption and improving technological processes are methods that require more costs.

The search for waste reduction options is a permanent task for the responsible staff to achieve the company's goals, because the reduction of production waste also reduces labour costs, which affect the company's profit. For companies, it is often appropriate to assess waste reduction opportunities not only in terms of product cost and operating income. To that end, it is necessary not only to calculate the estimated cost of a product by possibly applying any waste reduction method and to predict the effect of these changes on 
revenue, but also to predict the likely positive environmental impact over the next decades. Harmful waste can also have an impact on the health of personnel. The application of mitigation measures (or completely elimination) is particularly welcome, as it not only improves the health of workers but also the microclimate in the collective.

\section{Processing of the evaluation results}

It is possible to agree with Genc's (2013) categorical and precise opinion that environmental protection in the company's activities is the compatibility of the company's social activities with the aim of preserving biodiversity and ecosystems, efficient and responsible use of resources (energy, production materials, etc.), protection of the environment and revitalization of abandoned land through the development of activities, the creation and production of products suitable for recycling, which consume less resources in the production processes, encouraging a more efficient use of energy and other resources. First of all, it is advisable to choose the most appropriate assessment measures for each environmental direction which were previously identified as the most effective in the current situation. Once the most suitable one is being implemented, it would be advisable to assess and other measures according to the same criteria, at the same time determining the order of their deployment. It is also possible to determine criteria of corporates possibilities for mentioned measure implementation in order to assess readiness to be more sustainable.

In the end, enterprises seeking meaningful sustainable development will want to implement all three of Genc's methods, at which point we would advise applying formula (4). This formula will assist the enterprise in determining which method to implement first. Drejeris et. al. (2013) suggested applying this formula for determining the relative level of target achievement $(\mathrm{R})$ :

$$
R=\frac{\sum_{i=1}^{n} W_{i} \eta_{i}}{\sum_{i=1}^{n} W_{i}},
$$

where $i$ is the target index, $W_{i}$ the estimate of achievement of the target (scope of environmental targets), $\eta_{i}$ the significance of the target and $n$ the number of environmental targets.

It is advisable, with the expert method, to establish the implementation ranking of the previously best evaluated measures according to all environmental protection directions (i.e. according to the calculated R-index). The results of the relative level of target achievement may lead to the choice of company strategy.

\subsection{Strategic decision making}

Environmental elements also have a significant impact on other components of sustainable development: the social and economic situation in the company. The choice of resource type, the qualitative and quantitative use of energy clearly affects not only the environmental but also other components of sustainable development mentioned (Zadeh et al, 2016). It has been mentioned that it is difficult for businesses to find a strategic solution for all the results of the actions envisaged in the model, as the implementation of these measures is often foreseeable for a long time and requires considerable cost. The speed of 
decision making depends on the experience of companies, the situation on the market. The decision itself of companies to work towards sustainability is a positive and welcoming phenomenon. However, some measures may be too complex for small companies starting their activity (for example, the creation and application of technologies without waste, etc.). It is expedient for such companies to choose the measures already taken by the leaders of the field and in this way to go at least a step towards operational sustainability, by passing other companies that do not apply environmental protection measures. Every step towards sustainability improves the long-term economic results of enterprises (Paul et al., 2014). However, often lack of strategic thinking prevents companies from pursuing sustainable development (Baumgartner and Korhonen, 2010). Environmental protection is a crucial part of enterprise business strategy. On the other hand, companies have the right to choose whether to include environmental protection in their business strategy (Creel and Timothy, 2010). Mutual integration of economic and environmental measures offers new opportunities, but companies can integrate environmental elements into business strategy only in close cooperation with stakeholders who initiate environmental protection actions. It relates to the competence and entrepreneurial skills of the company's owners or founders and reflects the company's values and changes in philosophy and culture of the organisation (Genc, 2013). Taking into account the experience gained, companies can focus on the environment at three levels: simple compliance with existing regulations, voluntary compliance with stricter environmental requirements than those prescribed by regulations, be a leader in the field of environmental protection, testing innovations in their activities, even proposing new legislative amendments regulating the activities of companies according to the leader's achievements. For companies pursuing sustainable development it is not enough to comply with universally accepted regulations or wait for new legislation, but in the present situation it is necessary to constantly review and evaluate all products and services that are produced from an environmental point of view BenitoHernandez et al., 2016). It remains to agree with Creel and Timothy (2010) opinion that the environmental performance of an enterprise can be effectively implemented by incorporating the company's strategy into international standards, implementing and meeting them. Thus, the search for opportunities for implementation of environmental protection measures, and the realization of the emerging opportunities are strategic decisions, the continuous pursuit of which improves the position of enterprises in the market and their performance results. After examining the proposed technical, organizational and financial opportunities for applying environmental measures in the company, company executives have to formulate alternatives to the development of strategic activities, which may include different amounts of environmental protection measures, scale, implementation time, etc. The evaluation criteria are offered by many authors (Strezov et al, 2017; Lopez and Frohn, 2018; Viglia et al., 2018). The criteria should be grouped in order to determine their significance (Veleva and Ellenbecker, 2001). Expert evaluation is necessary for the strategic decision making. The best valued strategic alternative will be considered as the basis of the company's strategy.

In recent times, a significant increase in the public attitudes towards nature and its protection, as well as the cardinal revaluation of the formed values in the light of the requirements of sustainable development, is characteristic of the whole world. Compliance with environmental protection requirements is a common challenge for corporate executives, because there appears a need for additional costs. According to Genc (2013) 
the application of environmental protection measures and company performance are closely linked. Environmental challenges are global in nature, thus any measures that help to overcome these challenges are of great significance not only at the enterprise level, but also become significant for the state or region. Enterprise executives need to understand that environmental problems are systemic and require a strategic approach for determining the environmental impact of human activities and the relationship between ecological processes (Barbien, 2013). The need for a strategic approach was clarified by Paul et al. (2014) stating that there must be a permanent and lasting link between business and the environment.

The inclusion of environmental protection measures in the company's strategy demonstrates that the company has chosen a sustainable development path that strengthens the company's competitiveness, provides new opportunities for action and encourages the development of low environmental harm technologies (Russell and Shiang, 2013). It cannot be admitted that sustainable development is an absolute limitation. In fact, they mean the establishment of certain limits according to the current level of technology and resources and the ability of the biosphere to absorb the effects of human activity (Petrovic et al., 2012). Sustainable development helps maintain a balance between nature and man makes the world safer for all forms of life. Seeking sustainable development emphasizes long-term goals and environmental commitments (Hart, 1995). Enterprise sustainability is often not equal, companies which implemented more environmental measures and, to a wider extent, are considered to be more environmentally friendly (Russell and Shiang, 2013). The proposed model is not finite. It refers only to today's environmental actions that can be improved depending on scientific achievements.

\subsection{Use in practice: the process model for corporate environmental protection}

The process model for corporate environmental protection initiated by the Lithuanian Ministry of Environment was originally used in order to assess the willingness of and possibilities for construction companies in Lithuania to develop sustainable environmental activities. The goal of the model was to properly allocate funds for the implementation of environmental measures. Questionnaires were prepared which consisted of four closed and four open questions. The essence of the measures was also briefly described. We did not try to go into engineering subtleties, although some business executives expanded the content of questionnaire with technical explanations. Managers were asked about the already implemented environmental measures listed in the model, the possibilities to implement them, the planned measures within the next 1-2 years and the intention to include these measures in the company's strategy for the next 5-10 years. 174 construction companies were interviewed, 110 of which were small (up to 50 people), and the rest were over 50 employees and we divided the companies by size in our reporting of initial responses. Such a survey will demonstrate suitability of the model as an instrument for strengthen the environmental sustainability of corporations, as it includes questions not only about already implemented measures mentioned in the model, but also about possibility of implementation them in the future. The results of research are useful to make decisions for Lithuanian Ministry of Environment also for the distribution of funds. The study lasted 6 months in 2018. 
The final results of the study are presented in Tables 1,2,3,4,5. Table 1 shows the number of already implemented measures.

Table 1 | Number of already implemented environmental measures until 2019

\begin{tabular}{|c|c|c|c|c|c|c|c|c|}
\hline \multirow{2}{*}{$\begin{array}{l}\text { Size of } \\
\text { company }\end{array}$} & \multicolumn{2}{|c|}{$\begin{array}{l}\text { Reduction of raw } \\
\text { materials use }\end{array}$} & \multicolumn{2}{|c|}{$\begin{array}{l}\text { Reduction of energy } \\
\text { resources use }\end{array}$} & \multicolumn{2}{|c|}{ Reduction of pollution } & \multicolumn{2}{|c|}{ Reduction of waste } \\
\hline & $\begin{array}{l}\text { Number of } \\
\text { companies }\end{array}$ & $\begin{array}{l}\text { Number of } \\
\text { measures }\end{array}$ & $\begin{array}{l}\text { Number of } \\
\text { companies }\end{array}$ & $\begin{array}{c}\text { Number of } \\
\text { measures }\end{array}$ & $\begin{array}{l}\text { Number of } \\
\text { companies }\end{array}$ & $\begin{array}{c}\text { Number of } \\
\text { measures }\end{array}$ & $\begin{array}{l}\text { Number of } \\
\text { companies }\end{array}$ & $\begin{array}{c}\text { Number of } \\
\text { measures }\end{array}$ \\
\hline $\begin{array}{l}\text { Small } \\
\text { companies }\end{array}$ & $\begin{array}{l}47 \\
24 \\
16\end{array}$ & $\begin{array}{l}1 \\
2 \\
3\end{array}$ & $\begin{array}{l}70 \\
16 \\
10\end{array}$ & $\begin{array}{l}1 \\
2 \\
3\end{array}$ & $\begin{array}{c}48 \\
27 \\
9\end{array}$ & $\begin{array}{l}1 \\
2 \\
3\end{array}$ & $\begin{array}{c}14 \\
10 \\
3\end{array}$ & $\begin{array}{l}1 \\
2\end{array}$ \\
\hline $\begin{array}{l}\text { Large } \\
\text { companies }\end{array}$ & $\begin{array}{c}37 \\
9 \\
4\end{array}$ & $\begin{array}{l}1 \\
2 \\
3\end{array}$ & $\begin{array}{c}40 \\
16 \\
6\end{array}$ & $\begin{array}{l}1 \\
2 \\
3\end{array}$ & $\begin{array}{c}34 \\
12 \\
4\end{array}$ & $\begin{array}{l}1 \\
2 \\
3\end{array}$ & $\begin{array}{l}30 \\
10\end{array}$ & $\begin{array}{l}1 \\
2\end{array}$ \\
\hline
\end{tabular}

Source: authors

Table 2 determines the number of companies which have the opportunities to apply measures but do not yet do so.

Table 2 | Companies have opportunities for applying measures, but do not yet apply them

\begin{tabular}{|c|c|c|c|c|c|c|c|c|}
\hline \multirow[t]{2}{*}{$\begin{array}{l}\text { Size of } \\
\text { company }\end{array}$} & \multicolumn{2}{|c|}{$\begin{array}{l}\text { Reduction of raw } \\
\text { materials use }\end{array}$} & \multicolumn{2}{|c|}{$\begin{array}{l}\text { Reduction of energy } \\
\text { resources use }\end{array}$} & \multicolumn{2}{|c|}{ Reduction of pollution } & \multicolumn{2}{|c|}{ Reduction of waste } \\
\hline & $\begin{array}{l}\text { Number of } \\
\text { companies }\end{array}$ & $\begin{array}{l}\text { Number of } \\
\text { measures }\end{array}$ & $\begin{array}{l}\text { Number of } \\
\text { companies }\end{array}$ & $\begin{array}{c}\text { Number of } \\
\text { measures }\end{array}$ & $\begin{array}{l}\text { Number of } \\
\text { companies }\end{array}$ & $\begin{array}{c}\text { Number of } \\
\text { measures }\end{array}$ & $\begin{array}{l}\text { Number of } \\
\text { companies }\end{array}$ & $\begin{array}{l}\text { Number of } \\
\text { measures }\end{array}$ \\
\hline $\begin{array}{l}\text { Small } \\
\text { companies }\end{array}$ & $\begin{array}{l}88 \\
22\end{array}$ & $\begin{array}{l}1 \\
2\end{array}$ & $\begin{array}{l}88 \\
22\end{array}$ & $\begin{array}{l}1 \\
2 \\
3\end{array}$ & $\begin{array}{c}78 \\
28 \\
4\end{array}$ & $\begin{array}{l}1 \\
2 \\
3\end{array}$ & $\begin{array}{l}88 \\
22\end{array}$ & $\begin{array}{l}1 \\
2\end{array}$ \\
\hline $\begin{array}{l}\text { Large } \\
\text { companies }\end{array}$ & $\begin{array}{c}41 \\
19 \\
4\end{array}$ & $\begin{array}{l}1 \\
2 \\
3\end{array}$ & $\begin{array}{c}42 \\
16 \\
6\end{array}$ & $\begin{array}{l}1 \\
2 \\
3\end{array}$ & $\begin{array}{c}48 \\
12 \\
4\end{array}$ & $\begin{array}{l}1 \\
2 \\
3\end{array}$ & $\begin{array}{l}38 \\
10\end{array}$ & $\begin{array}{l}1 \\
2\end{array}$ \\
\hline
\end{tabular}

Source: authors

Table 3 summarizes the data about companies planning to implement measures in the next 1-2 years. This data shows a strong commitment to implement the proposed measures and great potential to apply them.

Table 3 | Companies planning to implement measures in the next 1-2 years

\begin{tabular}{|c|c|c|c|c|c|c|c|c|}
\hline \multirow{2}{*}{$\begin{array}{l}\text { Size of } \\
\text { company }\end{array}$} & \multicolumn{2}{|c|}{$\begin{array}{c}\text { Reduction of raw } \\
\text { materials use }\end{array}$} & \multicolumn{2}{|c|}{$\begin{array}{l}\text { Reduction of energy } \\
\text { resources use }\end{array}$} & \multicolumn{2}{|c|}{ Reduction of pollution } & \multicolumn{2}{|c|}{ Reduction of waste } \\
\hline & $\begin{array}{l}\text { Number of } \\
\text { companies }\end{array}$ & $\begin{array}{l}\text { Number of } \\
\text { measures }\end{array}$ & $\begin{array}{l}\text { Number of } \\
\text { companies }\end{array}$ & $\begin{array}{l}\text { Number of } \\
\text { measures }\end{array}$ & $\begin{array}{l}\text { Number of } \\
\text { companies }\end{array}$ & $\begin{array}{l}\text { Number of } \\
\text { measures }\end{array}$ & $\begin{array}{l}\text { Number of } \\
\text { companies }\end{array}$ & $\begin{array}{l}\text { Number of } \\
\text { measures }\end{array}$ \\
\hline \multirow{3}{*}{$\begin{array}{l}\text { Small } \\
\text { companies }\end{array}$} & 20 & 1 & 12 & 1 & 22 & 1 & 16 & 1 \\
\hline & 11 & 2 & 10 & 2 & 6 & 2 & 12 & 2 \\
\hline & 8 & 3 & 8 & 3 & 2 & 3 & & \\
\hline \multirow{3}{*}{$\begin{array}{l}\text { Large } \\
\text { companies }\end{array}$} & 11 & 1 & 22 & 1 & 14 & 1 & 12 & 1 \\
\hline & 9 & 2 & 6 & 2 & 8 & 2 & 1 & 2 \\
\hline & 2 & 3 & 4 & 3 & 4 & 3 & & \\
\hline
\end{tabular}

Source: authors

The data in Table 4 shows the number of environmental measures which are scheduled to be implemented in the next 5-10 years. This data shows that even companies that do not currently have opportunities to implement environmental measures (as shown in Table 2) still have plans to carry out some sustainable activities in the future. 
Table 4 | Number of environmental measures planned to be implemented in the next 5-10 years

\begin{tabular}{|c|c|c|c|c|c|c|c|c|}
\hline \multirow{2}{*}{$\begin{array}{l}\text { Size of } \\
\text { company }\end{array}$} & \multicolumn{2}{|c|}{$\begin{array}{l}\text { Reduction of raw } \\
\text { materials use }\end{array}$} & \multicolumn{2}{|c|}{$\begin{array}{l}\text { Reduction of energy } \\
\text { resources use }\end{array}$} & \multicolumn{2}{|c|}{ Reduction of pollution } & \multicolumn{2}{|c|}{ Waste reduction } \\
\hline & $\begin{array}{l}\text { Number of } \\
\text { companies }\end{array}$ & $\begin{array}{l}\text { Number of } \\
\text { measures }\end{array}$ & $\begin{array}{l}\text { Number of } \\
\text { companies }\end{array}$ & $\begin{array}{l}\text { Number of } \\
\text { measures }\end{array}$ & $\begin{array}{l}\text { Number of } \\
\text { companies }\end{array}$ & $\begin{array}{l}\text { Number of } \\
\text { measures }\end{array}$ & $\begin{array}{l}\text { Number of } \\
\text { companies }\end{array}$ & $\begin{array}{l}\text { Number of } \\
\text { measures }\end{array}$ \\
\hline \multirow{3}{*}{$\begin{array}{l}\text { Small } \\
\text { companies }\end{array}$} & 70 & 1 & 75 & 1 & 70 & 1 & 68 & 1 \\
\hline & 18 & 2 & 16 & 2 & 31 & 2 & 19 & 2 \\
\hline & 12 & 3 & 6 & 3 & 9 & 3 & & \\
\hline \multirow{3}{*}{$\begin{array}{l}\text { Large } \\
\text { companies }\end{array}$} & 44 & 1 & 50 & 1 & 48 & 1 & 44 & 1 \\
\hline & 12 & 2 & 8 & 2 & 12 & 2 & 2 & 2 \\
\hline & 8 & 3 & 6 & 3 & 4 & 3 & & \\
\hline
\end{tabular}

Source: authors

The total results are presented in the Table 5. This data presents a general picture of the approach of Lithuanian construction companies to sustainability.

Table 5 | Total results of implementation environmental measures of the construction companies in Lithuania

\begin{tabular}{l|c|c|c|c}
\hline $\begin{array}{l}\text { Size of } \\
\text { companies }\end{array}$ & $\begin{array}{c}\text { Already } \\
\text { implemented } \\
\text { measures until 2019 }\end{array}$ & $\begin{array}{c}\text { Companies have the } \\
\text { opportunities to apply } \\
\text { measures, but do not yet } \\
\text { apply them }\end{array}$ & $\begin{array}{c}\text { Companies planning to } \\
\text { implement measures in } \\
\text { the next 1-2 years }\end{array}$ & $\begin{array}{c}\text { Companies planning to } \\
\text { implement measures in } \\
\text { the next 5-10 years }\end{array}$ \\
\hline $\begin{array}{l}\text { Small } \\
\text { companies }\end{array}$ & $70(63 \%)$ & $88(80 \%)$ & $24(22 \%)$ \\
$\begin{array}{l}\text { Large } \\
\text { companies }\end{array}$ & $40(62 \%)$ & $48(75 \%)$ & $16(25 \%)$ & $50(78 \%)$ \\
\hline
\end{tabular}

Source: authors

The following six experts participated in the assessment of the responses to the previous questions regarding readiness and possibilities to implement environmental measures:

1. Head of department of construction agency (E1).

2. Group coordinator for environmental policy implementation of Ministry of Environment (E2).

3. Vice-Head of the Commission for Sustainable Development Lithuania (E3).

4. Head of investments department of Municipality (E4).

5. Construction inspector of Ministry of Environment (E5).

6. Independent construction expert (E6).

Prior to their assessment, it was important to establish criteria for the assessment in order that the assessment could be as objective as possible (Drejeris and Miceikiene, 2018). To do this, we proposed a scale of 100 points and total estimates are calculated as follows:

$$
W_{i}=\sum_{e=1}^{n} W_{i e}, i=\overline{1, m}
$$

where $W_{i e}$ is an estimate of the $i$-th question by the e-th expert, $n$ is the number of experts and $W_{i}$ is the sum of all $i$ question estimates by all experts.

The equation below is used to establish the relative importance of one of the questions: 


$$
n_{i}=\frac{W_{i}}{\sum_{i=1}^{m} W_{i}}, i=\overline{1, m},
$$

In this case, the sum of the importance of all questions will always equal one:

$$
\sum_{i=1}^{m} n_{i}=1,
$$

If the result is more than one, there must be a calculation error. The results of the experts'

\begin{tabular}{|c|c|c|c|c|c|c|c|}
\hline & $\begin{array}{c}\text { Expert } \\
(\mathrm{E} 1)\end{array}$ & $\begin{array}{l}\text { Expert } \\
\text { (E2) }\end{array}$ & $\begin{array}{c}\text { Expert } \\
\text { (E3) }\end{array}$ & $\begin{array}{c}\text { Expert } \\
(\mathrm{E} 4)\end{array}$ & $\begin{array}{c}\text { Expert } \\
\text { (E5) }\end{array}$ & Total & Sig. \\
\hline $\begin{array}{l}\text { Number of already implemented } \\
\text { environmental measures as of } \\
2019\end{array}$ & 50 & 30 & 35 & 30 & 40 & 185 & 0.37 \\
\hline $\begin{array}{l}\text { Having opportunities, but not yet } \\
\text { applying measures }\end{array}$ & 20 & 25 & 30 & 20 & 15 & 110 & 0.22 \\
\hline $\begin{array}{l}\text { Plans to implement measures in } \\
\text { the next } 1-2 \text { years }\end{array}$ & 20 & 25 & 25 & 30 & 30 & 130 & 0.26 \\
\hline $\begin{array}{l}\text { Number of environmental } \\
\text { measures planned to be } \\
\text { implemented in next 5-10 years }\end{array}$ & 10 & 20 & 10 & 20 & 15 & 75 & 0.15 \\
\hline Total & 100 & 100 & 100 & 100 & 100 & 500 & 1.00 \\
\hline
\end{tabular}
assessment are presented in Table 6:

Table 6 | Significance of the questions (criteria)

Source: authors

In this case, companies' possibilities and readiness to implement environmental measures can be calculated using the formula:

$$
K=\sum P_{i j} \cdot n_{i}
$$

Where $K$ is the possibilities and readiness of a company to implement environmental measures, $n$ the significance of the questions (criteria) and $P$ the number of measures $j$ according to the questionnaire.

Given that the opinions may often differ, we used the Kendall's Concordance Coefficient, calculated based on the ranking of the compared questions, to allow for the comparability of their opinions. Each question $\boldsymbol{g}_{\boldsymbol{i}}$ was linked to each expert's ranking of it, $r$ (Kendall, 1970):

$$
\overline{g_{i}}=\sum_{j=1}^{r} g_{i j}
$$

To be more precise, this was linked to the amount of deviations of individual opinions of a given question $g_{i}$ from the total mean $g$ for all questions: 


$$
\bar{S}=\sum_{i=1}^{m}\left(g_{i}-g\right)^{2}
$$

The total mean value $g$ is calculated also according to the formula:

$$
\bar{g}=\frac{\sum_{i=1}^{m} g_{i}}{m}=\frac{\sum_{i=1}^{m} \sum_{j=1}^{r} g_{i j}}{m}
$$

If $S$ is a real amount of squares calculated in accordance with formula (10), the concordance coefficient $\mathrm{W}$ is calculated in accordance with the following formula (Kendall, 1970):

From this, the Kendal Concordance Coefficient $W$ may be recalculated as (Kendall, 1970):

$$
W=\frac{12 S}{r^{2} m\left(m^{2}-1\right)}
$$

If the opinions of experts are harmonized, the value of the $W$ is close to 1 , whereas, if the assessment differ considerably, the value of $W$ is close to zero.

Referring to Table 1, it was determined that the sum of squared deviations $S$, which was calculated according to formula (2), amounts to $S=1700$, the concordance coefficient $W$ calculated according to formula (3) amounts to $W=0.823$. $W$ is close to 1 and this shows that the opinions of the experts were harmonized. With harmonized opinions, the opinions of the experts were able to be used to confidently allocate funding for environmental measures. Of the companies, Jonavos Statyba was ranked as the best candidate to receive funding, followed by a Vilnius house-building factory and JSC Roads of Kaunas. It should be noted that while these companies had the best attitude towards sustainability based on the criteria used, none of them planned to include in their strategies all four measures

\begin{tabular}{|c|c|c|c|c|c|c|c|}
\hline $\mathrm{C}^{-}$Experts & E1 & E2 & E3 & E4 & E5 & $\begin{array}{l}\text { The Total } \\
\text { of the } \\
\text { rankings }\end{array}$ & Ranking \\
\hline $\begin{array}{l}\text { Number of already implemented } \\
\text { environmental measures until } \\
2019\end{array}$ & 1 & 1 & 1 & 1 & 1 & 5 & 4 \\
\hline $\begin{array}{l}\text { Having the opportunities, but do } \\
\text { not yet applying measures }\end{array}$ & 2 & 2 & 2 & 3 & 4 & 13 & 3 \\
\hline $\begin{array}{l}\text { Plans to implement measures in } \\
\text { the next } 1-2 \text { years }\end{array}$ & 4 & 3 & 3 & 2 & 2 & 14 & 2 \\
\hline $\begin{array}{l}\text { Number of environmental } \\
\text { measures planned to be } \\
\text { implemented in } 5-10 \text { years }\end{array}$ & 3 & 4 & 4 & 4 & 3 & 18 & 1 \\
\hline
\end{tabular}
outlined in this paper to reduce energy use.

Table 7 | Ranking results

Source: authors 
Our results showed an intriguing trend that smaller companies tend to spot opportunities to implement environmental measures more than larger companies do. This supports the idea that smaller companies have greater flexibility and better ability to adapt to market needs, however a full analysis of all the reasons for this trend would be a topic for our further research. Nevertheless, the majority of companies surveyed have already implemented environmental measures and plan to continue implementing these measures in the future. Finally, our results show that, although our proposed model was designed for corporate environmental development purposes, it may also be used in the development of public sustainability goals.

\section{Conclusion}

Both global trends and consumer needs create the interest of companies in pursuing sustainable environmental protection activity. The application of environmental measures brings economic benefits to companies. However, neither in science nor in the special literature there is information provided on the environmental actions necessary for companies pursuing sustainable development. The article discusses the relevance of sustainable development and its resolution in the environmental protection activities of corporates, the possibilities and the need to integrate this component into the company's strategy.

Based on the sources of literature a model has been prepared for realization of environmental protection actions. The application of these actions in the company's activity would allow to gradually approach the sustainability of the company's activities. The model consists of the following components: reduction of use of raw materials, reduction of use of energy resources, reduction of pollution, reduction of waste, evaluation of the application possibilities of these processes, processing of results and strategic decision making.

Reasonable sequence of these actions' execution and content of all components of the model is suggested. After examining the possibilities of applying the measures mentioned in the model, company executives formulate strategic alternatives for business development, which is expedient to be assessed by an expert method. The best alternative identified in the current situation becomes the basis of the company's environmental protection strategy. The application of the model will allow companies to understand their possibilities to become more sustainable, also to objectively determine the order of environmental measures use and their content. The model was approved by Lithuanian construction companies.

The application of the model will also help public institutions distributing funds for environmental purposes by projects according to sorting the companies by attitude and opportunities to implement measures for environmental protection. Testing of the model allowed an assessment of the readiness companies for sustainable development, and this helped the Public institution of Environment to allocate funds to project participants. The applicability of the model and its suitability has been approved by Lithuanian construction companies. 


\section{Acknowledgement}

We confirm that this work is original and has not been published elsewhere, nor is it currently under consideration for publication elsewhere. We thank our colleagues, who provided expertise that greatly assisted the research.

\section{References}

Ayres, R. U. (2008). Sustainability Economics: where do we stand? Ecological Economics, 67(2), 281310. http://www.sciencedirect.com/science/article/pii/S0921-8009(07)00608-8

Barbien, D. (2013). What makes an Enterpise Sustainable? University of Erlangen - Nürnberg Information Systems, 1, 38-46.

Baumgartner, R. J., \& Korhonen, J. (2010). Strategic Thinking for Sustainable Development. Sustainable Development, 18, 71-75. https://doi.org/10.1002/sd.452.

Bélanger, F., \& Crossler, R. E. (2011). Privacy in the Digital age: a Review of Information Privacy Research in Information. Systems: Journal MIS Quarterly, 35(4), 1017-1042. https://www.jstor.org/stable/41409971.

Benito-Hernández, S., Platero-Jaime, M., \& Esteban-Sánchez, P. (2016). The Influence of Cooperative Relations of Small Businesses on Environmental Protection Intensity. Business Ethics: A European Review, 25, 416-439. https://doi.org/10.1111/beer.12126.

Brown, C. B., Waldron, S. A, \& Wilkins, J. F. (2017). Specialization and Intensification of Farming Systems in Western China: the Case of Dairy Farmers in Tibet. Journal of Agribusiness in Developing and Emerging Economies, 7(1), 2-14.

Cheng, C. C., \& Shiu, E. C. (2012). Validation of a proposed instrument for measuring eco-innovation: An implementation perspective. Technovation, 32, 329-344.

Creel, S., \& Timothy, S. (2010). Environmental Reporting Practices of the Largest U.S. Companies. Management Accounting Quarterly, 12(1), 13-19.

Dangelico, R. M., \& Pujari, M. (2010). Mainstreaming Green Product Innovation: Why and How Companies Integrate Environmental Sustainability. Journal of Business Ethics, 95, 471-486. https://doi.org/10.1007/s10551-010-0434-0.

Doh, J. P., \& Guay, T. R. (2006). Corporate Social Responsibility, Public Policy, and NGO Activism in Europe and the United States: An Institutional-Stakeholder Perspective. Journal of management studies, 43(1), 47-73.

Dornfeld, D. A., Jawahir, I. S., Clarens, A. F., \& Altman, K. (2013). Environmental Leadership: from Compliance to Competitive Advantage. Academy of Management Executive, 8(2), 7-20. https://doi.org/10.5465/ame.1994.9503101163.

Drejeris, R., Bivainis, J., Tunčikienè, Ž., \& Drejerienè, E. (2013). Determining the Purposefulness of New Services on the grounds of the Results of Quantitative Analysis. Journal of Business Economics and Management, 14(4), 791-805. doi:10.3846/16111699.2013.772917.

Drejeris, R., \& Miceikienè, A. (2018). Multi-Criteria Measurement of Sustainable Innovativeness in Farming Organisations: Evidence from Lithuania. Sustainability, 10(9), 33-47. https://doi.org/10.3390/su10093347

Elsaid, S., \& Aghezzaf, L-H. (2015). A Framework for Sustainable Waste Management: Challenges and Opportunities. Management Research Review, 38(10), 1086-1097. 
Everingham, Y., Inman-Bamber, G., Sexton, J., \& Stokes, C. (2015) A Dual Ensemble Agroclimate Modelling Procedure to Assess Climate Change Impacts on Sugarcane Production in Australia. Agricultural Sciences, 6, 870-888. http://dx.doi.org/10.4236/as.2015.68084.

Fifka, M.S., \& Berg, N. (2014). Managing Corporate Social Responsibility For The Sake Of Business and Society. Corporate Social Responsibility and Environmental Management, 21(5), 253-257. https://doi.org/10.1002/csr.1334.

Genc, K. Y. (2013). Natural Environment as a Strategic Issue for Firms: Theoretical Perspectives. Procedia - Social and Behavioral Sciences, 99, 143-153.

Glavič, P. \& Lukman, R. (2007). Review of Sustainability Terms and their Definitions. Journal of Cleaner Production, 15, 1875-1885. http://dx.doi.org/10.1016/j.jclepro.2006.12.006.

Hart, S., L. (1995). Natural-Resource-Based View of the Firm. Academy of Management Review, 20, 986-1014. https://doi.org/10.5465/amr.1995.9512280033.

Hellstrom, T. (2007). Dimensions of Environmentally Sustainable innovations: the Structure of Ecoinnovation Concepts. Sustainable Development, 15(3), 148-159. https://doi.org/10.1002/sd.309.

Cheng, C. C. \& Shiu, E. C (2012). Validation of a Proposed Instrument for Measuring Eco-innovation: an Implementation Perspective. Technovation, 32(6), 329-344.

Kendall, M. (1970). Rank Correlation Methods. London: Griffin.

Kshatri, N., \& Chouksey, A. (2014). Environmental Impact Assessment (EIA) study of Exploratory Oil well: A critical review. International Journal of Pharmacy and Life Sciences, 5(12), 4045-4048.

Lawrence, A., Thollander, P., Andrei, M., \& Karlsson, M. (2019). Specific Energy Consumption/Use (SEC) in Energy Management for Improving Energy Efficiency in Industry: Meaning, Usage and Differences. Energies, 12, 247-269.

Liddell, M. (2012). Little Blue Book of Scheduling. Florida: Joshua1nine Publishing; 2nd edition.

Lopez, R., \& Frohn, R. (2018). Remote Sensing for Landscape Ecology: New Metric Indicators. Boca Raton: CRC Press.

Magnusson, T., \& Johansson, G. (2008). Managing Internal Technology Transfer in Complex Product Development. European Journal of Innovation Management, 11(3), 349-365.

Narayana, S. A., Pati, R. K., \& Vrat, P (2012). Research on Management Issues in the Pharmaceutical Industry: a literature review. International Journal of Pharmaceutical and Healthcare Marketing, 6, 351-375.

Paul, I. D., Bhole, G. P., \& Chaudhari, J. R. (2014). A review on Green Manufacturing: It's important, Methodology and its Application. Procedia Materials Science, 6, 1644-1649.

Pena-Pereira, F., Kloskowski, A., \& Namieśnik, J. (2015). Perspectives on the Replacement of Harmful Organic Solvents in analytical Methodologies: a Framework toward the Implementation of a Generation of Eco-friendly Alternatives. Green Chemistry, 17, 3687-3705.

Petrovic, N., Slovic, D., \& Cirovic, M. (2012). Environmental Performance Indicatorsas Guidelines Towards Sustainability. Management Journal for Theory and Practice Management, 64, 5-15.

Poile, C., \& Safayeni, F. (2016). Using Computational Modeling for Building Theory: A Double Edged Sword. Journal of Artificial Societies and Social Simulation, 19(3), 8-28. http://jasss.soc.surrey.ac.uk/19/3/8.html. 
Roberts, K. G., Gloy, B. A., Joseph, S., Scott, N. R., \& Lehmann, J. (2010). Life Cycle Assessment of Biochar Systems: Estimating the Energetic. Economic and Climate Change Potential. Environental Science and Technology, 44(2), 827-833. https://doi.org/10.1021/es902266r.

Rothaermel, F. T. (2016). Competitive Advantage in Technology Intensive Industries. In: Thursby M. C. (ed.) Technological Innovation: Generating Economic Results. Bingley: Emerald Group Publishing Limited.

Russell, D. A., \& Shiang, D. L. (2013). Thinking about More Sustainable Products: Using an Efficient Tool for Sustainability Education, Innovation, and Project Management to Encourage Sustainability Thinking in a Multinational Corporation. ACS Sustainable Chemical Engineering, 1(1): 2-7. https://doi.org/10.1021/sc300131e.

Shelton, J, Martek, I., \& Chen, C. (2016). Implementation of Innovative Technologies in Small-scale Construction Firms: Five Australian case studies. Engineering. Construction and Architectural Management, 23, 177-191.

Skocaj, D. M., Everingham, Y., \& Schroeder, B. L. (2013). Nitrogen Management Guidelines for Sugarcane Production in Australia: Can These Be Modified for Wet Tropical Conditions Using Seasonal Climate Forecasting? Springer Science Reviews, 2, 51-71. http://dx.doi.org/10.1007/s40362-013-0004-9.

Strezov, V., Evans, A., \& Evans, T.J. (2017). Assessment of the Economic, Social and Environmental Dimensions of the Indicators for Sustainable Development. Sustainable Development, 25(3), 242-253.

Thoren, A., \& Vinberg, B. (2000). Pocket Book of Packaging. Packforsk: Kista.

Tietenberg, T., \& Lewis, L. (2018). Environmental and Natural Resource Economics. Oxford: Routledge.

Veleva, V., \& Ellenbecker, M. (2001). Indicators of Sustainable Production: Framework and Methodology. Journal of Cleaner Production, 9, 519-549.

Viglia, S., Civitillo, D. F., Cacciapuoti, G., \& Ulgiati, S. (2018). Indicators of Environmental Loading and Sustainability of Urban Systems. An Emergy-based Environmental Footprint. Ecological Indicators, 94, 82-99. https://doi.org/10.1016/j.ecolind.2017.03.060

Zadeh, R. S., Xuan, X., \& Shepley, M. M. (2016). Sustainable Healthcare Design: Existing Challenges and Future Directions for an Environmental, Economic, and Social Approach to Sustainability. Facilities, 34, 264-288. https://doi.org/10.1108/F-09-2013-0067.

The research paper has been reviewed. | Received: July 12, 2019; Revised: October 28, 2019; Accepted: November 6, 2019; Prepublished online: January 24, 2020; Published: January 30, 2020 